ど、魅力的な謎は数多く残されている。本実験系を活用 して解析が進展することが期待される。

本論文は、Whole brain-pituitary in vitro preparation of the transgenic medaka (Oryzias latipes) as a tool for analyzing the differential regulatory mechanisms of LH and FSH release (Karigo T, Aikawa M, Kondo C, Abe H, Kanda S, Oka Y) と題し、Endocrinology, (2014) 155, 536-547に発 表した。

\section{文 献}

1 ) Yaron Z, et al. Int Rev Cytol, 225, 131-185 (2003).

2) Nagai T, et al. Proc Natl Acad Sci USA, 98, 3197-3202 (2001).

3 ) Kanda S, Okubo K, Oka Y. Gen Comp Endocrinol, 173, 253-258 (2011).

4 ) Karigo T, et al. Endocrinology, 153, 3394-3404 (2012).

5 ) Tse A, et al. Science, 260, 82-84 (1993).

6 ) Chang JP, et al. Gen Comp Endocrinol, 161, 42-52 (2009).

\title{
トビハゼの闘争行動におけるアルギニンバソトシンの役割
}

加川 尚 (近畿大 $\cdot$ 理工・生命科学)

E-mail: kagawa@life.kindai.ac.jp

\section{1.はじめに}

アルギニンバソトシン (VT) およびイソトシン (IT) は 魚類から鳥類に至る脊椎動物が有する神経ペプチドであ り、それぞれ哺乳類のアルギニンバソプレシン (VP) お よびオキシトシン (OT) のホモログである。視床下部領 域に局在するこれらホルモンの産生ニューロンは、下垂 体を含む脳の様々な領域に投射し、浸透圧や血圧の調節 に機能する他、ストレス応答、生殖や社会行動の制御な どにも関与することが知られている ${ }^{1 \sim 3)}$ 。特に魚類にお けるVTと生殖、社会行動との関連性については、多岐 に渡る種で報告されているが、その多くが海水または淡 水に生息する種に関する研究である。我々は、浸透圧調 節や社会行動制御といつたVTの多機能性を同時に評価 できる可能性のある実験モデルとして、汽水域に生息す る魚種であるトビハゼ (Periophthalmus modestus) に着目 した。本種は河口域に生息する両生魚であり、浸透圧調 節機構を解明する優れた実験モデルであるとともに、野 外では縄張り競争が頻繁に観察されることが知られてい $3^{4,5)}$ 。そこで本研究では、トビハゼにみられる競争行 動を観察するための水槽試験系の確立と、本種の競争行 動制御におけるVTの役割について考察することを目的 とした。

\section{2. 雄性間競争試験とVTおよびIT mRNA 発現}

プラスチック製の陸地と $10 \mathrm{ppt}$ 海水を入れた行動試験 水槽に、体サイズがほぼ等しい雄 2 個体を入れて行動観 察を 1 時間行った。異なる個体を用いて計6回の行動試 験を行ったところ、水中では多岐に渡る攻撃行動パ夕ー
ンが多く観察され、攻撃行動回数の多い勝者と少ない敗 者が得られた。一方、陸上で攻撃行動を示した個体は 1 個体の勝者のみであり、その行動パターンも1項目に留 まった。水中における勝者の攻撃行動回数は敗者よりも 有意に高かった (表 1$)$ 。行動試験中に陸地に上陸する回 数および陸地に滞在した時間を計測したところ、いず れに関しても勝者は敗者よりも有意に高值を示した (図 1)。さらに、攻撃行動回数と陸地滞在時間との間には 有意な正の相関が認められた。これらのことからトビハ ゼでは水中における雄性間競争の勝敗が陸地への上陸 機会に影響することが示唆された。競争後の脳内VTお よびIT mRNA発現量を real time RT-PCRにて解析した 結果、VT mRNA発現量は敗者の方が勝者よりも有意に 高い值を示した (図2A)。また両者間でIT mRNA発現 量に差はなかった (図2B)。これらのことからトビ八ゼ 雄性間競争においてVTが何らかの機能を有することが 示唆された。魚類では脳内VTは3つの異なる視索前野 領域 (pPOA, mPOA, gPOA) で産生され、それぞれに特 有な生理機能をもつと考えられている。このうち $\mathrm{pPOA}$ のVTは攻撃性の低い個体において高発現することや ${ }^{6)}$ ストレス応答と連関することが報告されている7）しか し、本研究でみられたトビ八ゼの敗者における高いVT 発現は攻撃を受けることによるストレス応答では完全に 説明できない。なぜなら、行動試験後のトビ八ゼの勝者 と敗者との間で、ストレス応答の指標である血中コルチ ゾル濃度に差異はなかったからである(図2C)。トビハ ゼのような両生魚ではVTが従来知られている機能の他 に、陸から水中への移動行動や水中環境への適応にも機

表1 雄性間競争試験の勝者および敗者にみられる攻撃行動頻度 (行動回数／時間)

\begin{tabular}{|c|c|c|c|c|c|c|c|c|}
\hline \multirow[b]{2}{*}{ 競争個体 } & \multicolumn{6}{|c|}{ 水中 } & \multirow{2}{*}{$\begin{array}{c}\text { 陸上 } \\
\begin{array}{l}\text { Operculum } \\
\text { display }\end{array}\end{array}$} & \multirow[b]{2}{*}{ 合計 } \\
\hline & Fin display ${ }^{a}$ & $\begin{array}{l}\text { Operculum } \\
\text { display }\end{array}$ & Replace & Chase & Bite & Attack & & \\
\hline 勝者 & $7.6 \pm 1.6^{*}$ & $5.6 \pm 2.1$ & $3.5 \pm 1.4$ & $0.2 \pm 0.2$ & $2.8 \pm 1.7$ & $10.3 \pm 2.7$ & $1.0 \pm 1.0$ & $29.6 \pm 4.0^{* *}$ \\
\hline 敗者 & $4.5 \pm 0.6$ & $2.3 \pm 1.6$ & $1.3 \pm 1.6$ & $0.2 \pm 0.2$ & $0.5 \pm 2.0$ & $8.5 \pm 2.7$ & $0.2 \pm 0.2$ & $17.5 \pm 6.0$ \\
\hline
\end{tabular}



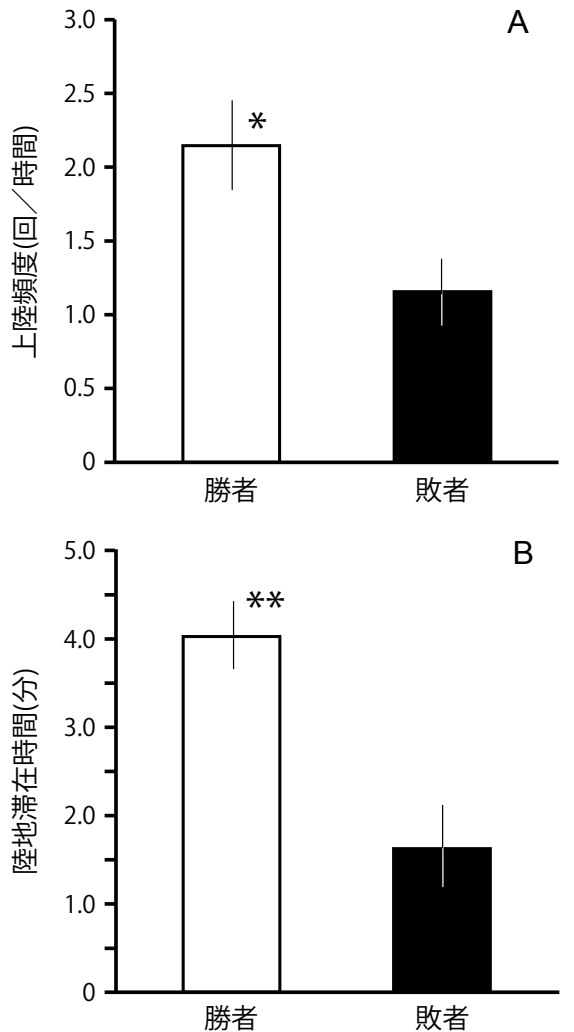

図1 勝者および敗者が水中から陸地へ移動した頻度 $(\mathrm{A})$ お よび陸地に滞在した合計時間 (B)

デー夕は6個体の平均土標準䛊差.*および**, 敗者に比べて 有意差あり（それぞれ $\mathrm{P}<0.05$ および $\mathrm{P}<0.01)$.

能するのかもしれない。今後は浸透圧調節機能と合わせ て、水中への移動行動制御に及ぼすVTの機能解明が望 まれる。

\section{VT脳室内投与が攻撃行動に及ぼす影響}

トビ八ゼ雄の攻撃行動に及ぼすVTの影響を調べるた めに、VT (5または $500 \mathrm{pg} / \mathrm{g}$ 体重)を脳室内投与した個 体と溶媒のみ投与したコントロール個体を競争行動試験 に供した。なお、前述の行動試験では攻撃行動が陸上で はほとんどみられず水中で高頻度に観察されたことから、 本実験では陸地のない水環境のみの水槽を用いた。その 結果、いずれの濃度のVTを投与した群においても、コ ントロール群より有意に高い攻撃行動回数を示した (表 2)。VT投与による攻撃行動の元進については他魚種 でも報告されている ${ }^{3)}$ 。また、攻撃性の高い個体では gPOAのVT発現が高いことも知られている ${ }^{6}$ 。これら
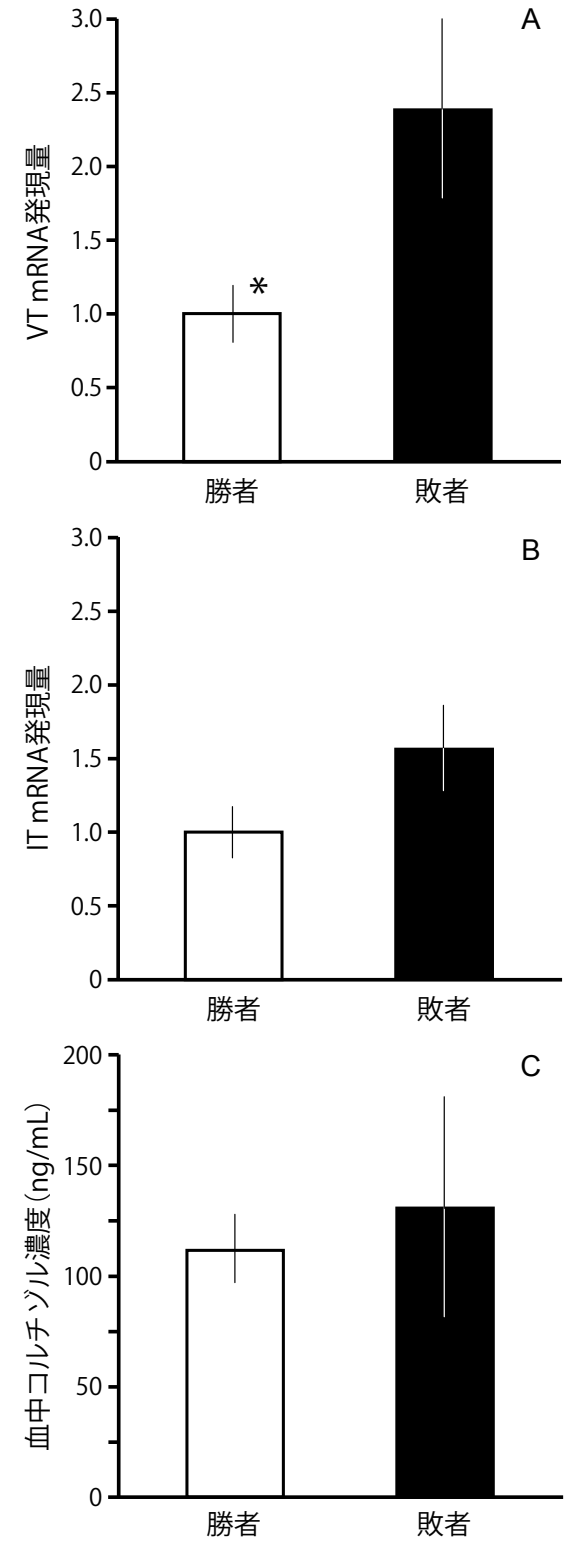

図2 勝者および敗者におけるVT mRNA発現量 $(A) 、 I T$ mRNA 発現量 (B) および血中コルチゾル濃度 $(C)$ データは6個体の平均土標準誤差。*,敗者に比べて有意差あ り $(\mathrm{P}<0.05)$.

のことからトビハゼにおいてもVTは攻撃行動充進に機 能すると考えられる。本種における各脳領域のVT発現 については、今後、免疫染色法や in situ hybridization法 による組織学的発現解析を行い、VTの詳細な機能解明 を行う予定である。

表2 高濃度 (500 pg/g-bw.) または低濃度 (5 pg/g-bw.) VT投与個体とコントロール個体の競争試験にみられる攻撃行動頻度 (行動回数 / 時間)

\begin{tabular}{cccccccc}
\hline 競争個体 & Fin displaya & $\begin{array}{c}\text { Operculum } \\
\text { displayb }\end{array}$ & Replace & Chase & Bite & Attack & 合計 \\
\hline コントロール & $0.8 \pm 0.3$ & $0.2 \pm 0.2$ & $0.3 \pm 0.2$ & $0.3 \pm 0.2$ & $0.3 \pm 0.2$ & $1.3 \pm 0.5$ & $3.3 \pm 0.7$ \\
VT (低濃度) 投与 & $0.7 \pm 0.2$ & $0.3 \pm 0.2$ & $2.7 \pm 0.6^{*}$ & $0.5 \pm 0.3$ & $1.5 \pm 1.0$ & $4.5 \pm 1.1$ & $10.2 \pm 2.1^{*}$ \\
\hline コントロール & $1.2 \pm 0.3$ & $0.3 \pm 0.2$ & $0.7 \pm 0.3$ & $0.5 \pm 0.3$ & $0.3 \pm 0.2$ & $1.5 \pm 0.8$ & $4.5 \pm 1.8$ \\
VT (高濃度) 投与 & $3.5 \pm 0.6^{* *}$ & $2.3 \pm 0.8^{* *}$ & $2.2 \pm 0.5$ & $1.5 \pm 0.4$ & $1.7 \pm 0.4$ & $8.7 \pm 2.5^{* *}$ & $19.8 \pm 3.2^{* *}$ \\
\hline
\end{tabular}

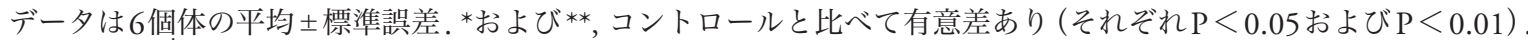

a, 背鯺拡張。 ${ }^{,}$開口および鰓蓋拡張. 


\section{4.まとめ}

本研究により、両生魚であるトビハゼが、雄性間競争 にみられる攻撃、上陸、進水といつた種々の行動制御に おける内因性 VTの多機能性を解明するうえで、極めて 有用な実験モデルであることが示された。

本論文は、Potential roles of arginine-vasotocin in the regulation of aggressive behavior in the mudskipper (Periophthalmus modestus) (Kagawa, N., Y. Nishiyama, K. Kato, H. Takahashi, Y. Kobayashi, H. Sakamoto, T. Sakamoto) と題し、 Gen. Comp. Endocrinol. (2013) 194, 257-263に発表した。

\section{文 献}

1 ) Goodson JL, Bass AH. Brain Res Rev, 35, 246-265 (2001).

2) Hyodo S, Urano A. J Comp Physiol B, 161, 549-556 (1991).

3 ) Semsar K, et al. Horm Behav, 40, 21-31 (2001).

4 ) Sakamoto T. Physiol Behav, 104, 923-928 (2011).

5 ) Clayton D. Oceanogr. Mar. Biol.: an annual rev, 31, $507-$ 577 (1993).

6 ) Kagawa N. J Fish Biol, 82, 354-363 (2013).

7 ) Gilchriest BJ et al. J Neuroendocrinol, 12, 795-801 (2000).

\title{
レプチン受容体KO メダカの解析 一摂飭制御系、摂䬲量、成長、脂肪蓄積に関して一
}

\author{
苣田 慎一 ( 水産総合研究セ・増養殖研) \\ ※2014年3月までの所属 \\ E-mail: chisada@affrc.go.jp
}

\section{1.はじめに}

1990年代、レプチン (Lep) 及びレプチン受容体 (LepR) 遺伝子は遺伝性肥満 (ob/ob、及び $\mathrm{db} / \mathrm{db}$ ) マウスの病因遺 伝子として同定され、Lepは視床下部に発現するLepRを 介して強力な摂食抑制作用を示すことが証明された 哺乳動物におけるレプチンシグナルは、摂食制御に加え、 繁殖、免疫機能、糖・脂質代謝等の制御に直接、もしく は間接的に作用し、それらによりエネルギー恒常性を維 持すると考えられている゙)。

魚類では2005年にトラフグで初めてLepが発見され ${ }^{4)} 、$ その後、様々な魚種にてLepと LepRが単離された。最 近の研究では、魚類 Lepの機能の一つに、哺乳動物と同 様な摂䭒関連神経ペプチドを介した摂餆抑制作用の存 在が示されている ${ }^{5,6)}$ 。一方、魚類と哺乳動物間で明ら かな違いも示された。まず、Lepオルソログのアミノ酸 配列間で相同性が低い ${ }^{4)}$ 。次に、魚類Lepの発現は主に 肝臓であるが ${ }^{7,8)}$ 、哺乳動物のそれは脂肪組織である ${ }^{1)}$ また、魚類では長期絶食により血中Lep 濃度が増加する 等の報告もある ${ }^{9,10)}$ 。これらは、魚類特有の Lep 機能の 存在を示唆している。

近年、メダカでは遺伝子ノックアウト $(\mathrm{KO})$ 技術が確 立され ${ }^{11,12)}$ 、孵化後から成魚以降における遺伝子機能解 析が容易となった。我々はその技術の一つである Targeting Induced Local Lesions In Genomes法により、LepR遺 伝子の leptin-binding domain 直前に位置するアミノ酸が 終止コドンに変異した LepR KOメダカを得た ${ }^{13)}$ 。本原 著論文では、表現型解析の第一段階として、間脳摂餌関 連ペプチドの発現、摂慨量、成長、脂肪蓄積に関するデ ータを示した。

\section{LepR KO メダカの摂慨制御系と摂䬶量}

Lepは POMC/CART 系 (食欲抑制系) の活性化と NPY/ AgRP系 (食欲促進系) の抑制に作用する。そこで、定 量PCRにより、各系の活性化の指標となる摂䬲関連ぺ プチドの間脳における転写産物量を調べた。その結果、 LepR KOメダカの間脳では、野生型 (WT) メダカと比 べて、摂餌前後においてNPYa及びAgRP mRNA量が有 意に増加しており、摄䭒後において POMC1量が有意に 低下していた (図 1$)$ 。次に、両メダカ間で摂餌量を比較 した結果 (方法は図2Aに示す)、LepR KOメダカの摂餌 量はWTメダカに比べて粰化後5週齢では 1.5 倍、16週 龄では1.7倍増加していた。以上より、メダカLepR遺 伝子機能の欠損は、間脳における食欲促進系の活性化と、 摂䬣量の増加をもたらしたと結論付けた。ただし、WT メダカの NPYa及びAgRP mRNA量が摂慨前と摂餌 2 時 間後で有意差が生じなかったこと、LepR KOメダカの

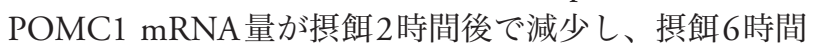
後に増加したことに関しては、様々な条件下で追跡調査 する必要がある。

\section{LepR KO メダカの成長曲線と内臓脂肪}

飽食給餌下に技けるLepR KOメダカの成長を、体 重、体長、肥満度 (各項目の挙動は同じ傾向であったた め、本誌では体重に関してのみ記載)、及び脂肪蓄積に 関して調べ、WTメダカと比較した。LepR KOメダカ の体重は睬化後5週齢でWTの2.1倍、7週齢でWTの 1.6 倍に達し、幼若魚期の著しい成長加速が認められた (図

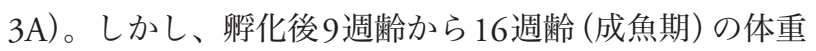
はWTメダカのそ扎らと統計的有意差は生じなかった (図3B)。成長比較試験と同条件下で飼育した成魚期前 の両メダカ、及び成魚期の WTメダカの内藏にはほと 